\title{
Taxonomy and morphology of Apsil Malloch (Diptera, Muscidae, Coenosiinae, Coenosiini) with new records, description of a new species and a key to identification
}

\begin{abstract}
Márcia S. Couri ${ }^{1,2}$
${ }^{1}$ Museu Nacional, Universidade Federal do Rio de Janeiro - Quinta da Boa Vista, 20940-040 Rio de Janeiro, Brasil ${ }^{2} \mathrm{CNPq}$ fellow.

ABSTRACT. Taxonomy and morphology of Apsil Malloch (Diptera, Muscidae, Coenosiinae, Coenosiini) with new records, description of a new species and a key to identification. Apsil Malloch (Diptera, Muscidae, Coenosiinae, Coenosiini) includes 10 species, most of them described from Chile, but some also from Argentina. Five of them and one new species were found at the California Academy of Sciences collection (San Francisco, California) during the course of a project developed in that institution. Almost all material studied was collected in Chile, mainly by M. E. Irwin, during the year of 1966. Brief diagnosis of the known studied species (A. apicata Malloch, A. atripes Malloch, A. dilata Malloch, A. maculiventris Malloch (female described for the first time) and A. spatulata, Malloch), the description of A. mallochi, sp. nov. and a key for the identification of all known species are given. Color illustrations of some morphological characters make easier the recognition of the species. New geographic records were assigned.
\end{abstract}

KEYWORDS. Apsil mallochi, n. sp.; diagnosis; key to identification; systematics.

RESUMO. Taxonomia e morfologia de Apsil Malloch (Diptera, Muscidae, Coenosiinae, Coenosiini) com novos registros, descrição de uma nova espécie e chave para identificação. Apsil Malloch (Diptera, Muscidae, Coenosiinae, Coenosiini) inclui 10 espécies, a maioria delas descrita do Chile, mas algumas também da Argentina. Cinco delas e uma espécie nova foram encontradas na coleção da Califórnia Academy of Sciences (São Francisco, California), durante projeto desenvolvido naquela instituição. Quase todo material foi coletado no Chile, principalmente por M. E. Irwin, durante o ano de 1966. Diagnoses das espécies conhecidas estudadas (A. apicata Malloch, A. atripes Malloch, A. dilata Malloch, A. maculiventris Malloch (fêmea descrita pela primeira vez) e A. spatulata, Malloch), descrição de $A$. mallochi, sp. nov. e uma chave de identificação para todas as espécies conhecidas são fornecidos. Ilustrações coloridas de alguns caracteres morfológicos facilitam o reconhecimento das espécies. Novos registros grográficos são assinalados.

PALAVRAS-CHAVE. Apsil mallochi, n. sp.; diagnoses; chave para identificação; sistemática.

Apsil was described by Malloch (1929), to a single species - A. maculiventris. Later (Malloch 1934) added 7 new species to the knowledge of the genus. Couri and Pont (2000) in the cladistic analysis of the world Coenosiini, proposed the synonymy of Raymondomyia Malloch with Apsil and so, the unique species described in this genus was added to ApsilA. flavipalpis.

Couri (2000) revised the nine Apsil species, including descriptions and illustrations of male and female terminalia and new records from south Chile were added to the distribution of some species.

Carvalho and Couri (2002) made a cladistic and biogeographical analysis of Apsil and Reynoldsia Malloch, both endemic to Patagonia and southern Chile. The monophyly of both genera was supported; the one of Apsil based in two synapomorphies, flat head and high gena. The cladistic biogeographic analysis of both genera showed a distribution pattern congruent with recent biogeographic reconstructions of southern South America as the ones in Morrone (1993, 1994) and Morrone et al. $(1994,1997)$.

Couri (2002) described one more species from Chile $-A$. diminuta.

Couri \& Carvalho (2002) gave a diagnosis of the genus, comments on its systematic position and presented a key for the known species, modified from the one presented by Malloch (1934).

Carvalho et al. (2005) catalogued the 10 known species as follows: A. apicata Malloch, 1934; A. atripes Malloch, 1934; A. biseta Malloch, 1934; A. dilata Malloch, 1934; A. diminuta Couri, 2002; A. flavipalpis (Malloch, 1934); A. maculipennis Malloch, 1934; A. maculiventris Malloch, 1929; A. pennata Malloch, 1934 and A. spatulata Malloch, 1934.

This contribution presents the results of the study of the six species of Apsil found at the California Academy of Sciences Diptera collection, including one new - A. apicata, A. atripes, A. dilata, A. maculiventris, A. spatulata and $A$. mallochi, sp. nov. Brief diagnosis of the known studied species, a full description of the new species and a key for the identification of all known species are given. Color illustrations of some morphological characters are also provided, making easier the recognition of the species.

\section{MATERIALAND METHODS}

Almost all material studied was collected in Chile, mainly by M. E. Irwin, during the year of 1966 and is deposited at the 
Diptera collection of California Academy of Sciences (CAS, San Francisco, California). Holotype of the new species will be deposited at CAS collection. Some specimens of $A$. atripes and $A$. maculiventris will be deposited at Museu Nacional, Rio de Janeiro collection (MNRJ) as indicated in the material examined.

Apsil species are not common in collections and also their series usually includes only few specimens. Some of the species found at CAS collection are also represented by small series, sometimes by only one specimen, except for $A$. atripes, where about 350 males and 500 females were identified.

The dissected terminalia was placed in glycerin in a microvial pinned with the respective specimen.

The color photos were made using Syncorscopy/JVC Auto-Montage equipment and an optical Leica M 420 microscope and the drawings were made in an optical microscope Olympus $\mathrm{CH}-2$ with camara lucida.

\section{DIAGNOSESAND DESCRIPTIONS}

Apsil Malloch. Diagnosis. [Ref. Couri, 2000]. Male dichoptic; eyes reduced in size; frons at vertex about onethird of the head width; face flat and wide; 1 pair of reclinate orbital seta; antenna short; arista with short cilia along its entire length; palpus slightly or very dilated at apex (Figs 7 and 14); gena high (Fig. 1); dorsocentrals 2:3; prealar seta absent; prosternum bare; katepisternals $1: 1: 1$ in an equilateral triangle; males with hypandrium tubular, and females with long ovipositor with microtrichia; tergites and sternites slender.

Distribution. ARGENTINA: (Lake Correntoso, Puerto Blest, San Carlos de Bariloche, Volcan). CHILE: Aisen (Coihaique); Araucania (Angol, Curacautin, Malalcahuello, Malleco); Atacama (Perales); Bio Bio (Concepcion); Coquimbo (Coquimbo); Libertador General Bernardo O'Higgin (Las Cabras); Los Lagos (Ancud, Casa Pangue, Castro, Osorno, Parque Nacional Puyehue, Peulla, Puntra); Maule (Curico, Talca); Nuble (Las Trancas); Região Metropolitana (El Canelo, Maipu, Santiago), Valparaiso (Rio Colorado).

Notes. Additional geographic records - Malleco (Araucania); El Canelo, Maipu, Santiago (Regiao Metropolitana) and Las Trancas (Nuble) - were added to the previously known distribution of the genus and will certainly help biogeographic reconstruction researches of the southern of South America.

Key to the species of Apsil Malloch

This key (with parts modified from Malloch (1934) and Couri and Carvalho (2002), is presented due to the variation in color, mainly of the legs, observed in the big examined series of $A$. atripes, which could difficult the use of the mentioned keys available in literature.

1. Anepimeron setulose (Argentina) .. A. flavipalpis Malloch Anepimeron bare. 2

2. Male: fore tibia thickened apically and with several series of erect lanceolate setae, about twice as long as tibial diameter; legs black, fore tarsi testaceous yellow; basal segment compressed, its greatest width exceeding that of apex of tibia, and its upper edge with a fringe of black setae that are decumbent and directed apically. Female: unknown (Argentina - San Carlos de Bariloche; Chile - Casa Pangue) ....

A. pennata Malloch

Male: without lanceolate setae on fore tibia; fore metatarsus not compressed.

3. Wing with a small dark spot on first posterior cell .......... 4 Wing without a small dark spot on first posterior cell ...... 5

4. Mid tibia with only one posterior seta at middle; hind tarsus over three-fourths as long as hind tibia and with the usual short posterior hairs. (Argentina - Lake Correntoso, Puerto Blest, Volcan); Chile - Coihaique, Curacautin Malalcahuello, Parque Nacional Puyehue) A. maculipennis Malloch

Mid tibia with one posterodorsal and one posterior mid setae; hind tarsus not two-thirds as long as hind tibia; with longer, denser and finer posterior hairs basally (Argentina - San Carlos de Bariloche, Volcan); Chile - Angol, Coihaique, Curacautin, Las Cabras, Malalcahuello). A. biseta Malloch

5. Abdomen with large brown marks occupying almost all dorsum of the tergites; palpus not conspicually dilated at apex. Female: unknown (Chile-Osorno) ........ A. diminuta Couri

Abdomen with gray dusted, tergites $1+2-4$ with a pair of large subtriangular black marks, and usually with a pair of sublinear marks on disc of tergite 5 (Fig. 24); palpus conspicually dilated at apex or not .......... 6

6. Palpus only slightly dilated at apex (Fig. 17) .................... 7 Palpus conspicually dilated at apex (Fig. 14) ................. 9

7. Fore femur with the posteroventral row of setae much stouter than the posterodorsal one (Fig. 16, A. maculiventris). Male: hind tibia elongated (Fig. 3); hind tarsus short, measuring about half the length of hind tibia sternite 5 glossy and with outstanding process (Fig. 5) (Argentina - Lake Correntoso, San Carlos de Bariloche; Chile - Casa Pangue, Santiago) A. apicata Malloch

Fore femur with the posteroventral row of setae not stouter than the posterodorsal one. Male: hind tibia elongated or not; hind tarsus varying in size in relation with hind tibia; sternite 5 not glossy or not and with or without outstanding process .8

8. Male: hind tibia not elongated; hind tarsus almost as long as hind tibia; sternite 5 not glossy and without outstanding process (Fig. 8) (Chile - Colorado, 
Concepcion, Curico, El Canelo, Maipu, Malleco, Nuble, Santiago, Talca) . A. atripes Malloch

Male: hind tibia elongated; hind tarsus measuring 1.5 the length of hind tibia; sternite 5 glossy and with outstanding process (Fig. 22) (Chile-Nuble). Female unknown A. mallochi, new species

9. Tibiae yellow, contrasting with the brown gray pollinose femora (Fig. 18). Male: hind femur with a clump of fine erect posterior hairs near base (Fig. 17) (Chile Malleco, Nuble, Perales, Santiago)

A. maculiventris Malloch

Tibia concolors with femora, usually brown gray pollinose; sometimes the tibia can be slightly yellowish, but never contrasting with the femora color. Male: hind femur without a clump of fine erect posterior hairs near base 10

10. Palpus spoon shaped (Fig. 10). Male. Hind coxa with 2 posterior strong spines (Fig. 11); process of sternite 5 with black strong setae (Fig. 12); (Argentina - San Carlos de Bariloche; Chile-Ancud, Castro, Puntra) .. A. dilata Malloch

Palpus paddle shaped. Male. Hind coxa without posterior spines; process of sternite 5 with yellow setae; (Argentina-San Carlos de Bariloche; Chile-Curico, Nuble, Peulla, Puntra). A. spatulata Malloch

\section{Apsil apicata Malloch, 1934}

(Figs. 1-5)

Diagnosis. Length $4.5 \mathrm{~mm}$. Gena very high, densely golden yellow dusted (Fig. 1); frons brown, gray pollinose; antennae brown, apex of pedicel and base of flagellomere reddish (from the original description, specimen with antennae missing); palpus yellow, slightly dilated at apex; dorsum of mesonotum with four brown vittae presuturally, the lateral ones broader and extending until margin of scutellum; and the inner ones thinner and extending until insertion of second pair of postsutural dorsocentral setae; postsuturally one median vitta almost reaching scutellum; scutellum brown with grayish pollinosity, with sides brownish (Fig. 2); legs with coxa, femur and tibia brown with grayish pollinosity; tarsi yellowish, especially on posterior surface; fore femur with the row of posteroventral setae much stouter than the one on posterodorsal; hind leg (Fig. 3) with femur much longer and stouter than fore and mid femora, with a complete row of anterodorsal and anteroventral setae; posteroventral surface with a row of setae on basal half; hind tibia long and curved, about twice the tarsi length, one thin supramedian anterodorsal seta; 3 anteroventrals on middle third; 3 posterodorsals on apical third hind tarsi short; abdomen brown with grayish pollinosity; with large subtriangular lateral brown marks on tergites 3-5 (Fig. 4). Sternite 5 glossy dark brown with an outstanding yellow bare process at tip (Fig. 5).
Material examined. CHILE: Regiao Metropolitana: Santiago: Quebrada de la Plata Fundo, near Maipu, $33^{0} 30^{\prime}$ S $70^{\circ} 55^{\prime}$ W, 510 m, ME Irwin, Malaise, 2 February 1966 (1 male). Coquimbo: Hacienda Illapel, Rio Illapel, 600-900 m, EI Schlinger and ME Irwin, 19 October 1966 (1 male)

Notes. These are new geographic records for the species, previously known from Correntoso, Rio Negro and Bariloche in Argentina and Casa Pangue (Los Lagos) in Chile.

\section{Apsil atripes Malloch, 1934}

(Figs. 6-8)

Diagnosis. Length 6-7 mm. Gena high, golden yellow dusted (Fig. 6); frons brown, with gray pollinosity; antennae brown, apex of pedicel and base of flagellomere yellowish; palpus yellow, slightly dilated at apex (Fig. 7); dorsum of mesonotum with four brown vittae presuturally, and 7 postsuturally (the two median ones can be more or less fused behind suture, especially on females); scutellum brown with grayish pollinosity, with lateral sides brown; legs brown with grayish pollinosity; tibia and tarsi show a gradual yellowish intensity in the examined series, especially in females; fore femur with the row of posteroventral setae not stouter than the posterodorsal; hind femur and tibia not elongated; hind femur with a complete row of anterodorsal and anteroventral setae; posteroventral surface with a row of setae on basal half; hind tibia not curved and about the same size as tarsi, one median anterodorsal seta; 2-3 thin anteroventrals on middle third; abdomen brown with grayish pollinosity, with large subtriangular lateral brown marks on tergites 3-4; tergite 5 with 2 longitudinal brown vittae; sternite 5 not glossy, yellow on arms and without outstanding process (Fig. 8).

Color variation. Malloch (1934) original description mentioned that this species differs from the others by the "legs entirely black". The big series examined showed a graduation of color, mainly in tibiae and tarsi, which can varies from brown with gray pollinosity, to slightly yellowish. The specimens who showed this variation, do not show any outstanding characters that could segregate them from $A$. atripes. Even considering this variation, the following combination of characters can easily distinguishes this species from its congeners: palpus slightly dilated at apex; posteroventral series of setae on fore femur not stouter than posterodorsal; hind tibia not elongated; hind tarsus almost as long as hind tibia and sternite 5 not glossy and without outstanding process.

Material examined. CHILE: Região Metropolitana: Santiago: Quebrada de la Plata Fundo, near Maipu, $33^{0} 30^{\prime} \mathrm{S} 70^{\circ} 55^{\prime} \mathrm{W}, 510$ m, ME Irwin, Malaise, 26 January 1966 (5 females); 28 January 1966 (1 female); 2 February 1966 (3 males, 1 female); 8 February 1966 (1 male, 1 female); 9 February 1966 (5 males, 5 females); 10 February 1966 (7 males, 1 female); 12 February 1966 ( 8 males, 2 females, 1 female MNRJ); 14 February 1966 ( 5 males, 5 females); 19 February 1966 (2 females); 20 February 1966 (1 male); 21 February 1966 (1 male, 12 females); 9 March 1966 (10 males, 1 male MNRJ, 20 females); 12 March 1966 (15 males, 57 females); 16 March 1966 (18 males, 25 females, 1 female MNRJ); 17 March 1966 (6 males, 4 females); 23 March 1966 (3 males, 
5 females); 24 March 1966 (7 males, 7 females); 550m; 14 February 1966 (1 male); 19 February 1966 (1 male, 1 female); 9 March 1966 (1 male); 12 March 1966 (36 males, 23 females); 16 March 1966 (14 males, 27 females); 17 March 1966 (9 males, 1 male MNRJ, 9 females, 1 female MNRJ); 22 March 1966 (1 male); 24 March 1966 (38 males, 36 females, 1 female MNRJ); 27 March 1966 (1 female); Maipu: Rinconada, 30 31' S 70 47', 510 m, 26 January 1966 (25 males, 12 females); 27 January 1966 (5 males, 3 females); 30 January 1966 (1 male); 20 February 1966 (1 female); 21 February 1966 (11 males); 9 March 1966 (3 females); 16 March 1966 (4 males, 4 females); 23 March 1966 (4 males, 20 females); 24 March 1966 (5 males, 1 male MNRJ, 12 females); 27 March 1966 (9 males, 1 male MNRJ, 16 females); 3 April 1966 (50 males, 73 females); 550 m, 19 February 1966 (1 female); 17 March 1966 (3 females); 22 March 1966 (4 males, 22 females); 23 March 1966 (7 males, 19 females); 27 March 1966 (20 males, 45 females); 550m, 19 April 1966 (1 male); El Canelo: $33^{0} 37^{\prime} \mathrm{S} 71^{0} 35^{\prime} \mathrm{W}$, 950 m, EI Schlinger, 10 January 1967 (1 male); Nuble: Las Trancas: 40 Km E of San Carlos, Ross and Michelbacher, 23 December 1950 (3 females); rd nr. Termas de Chillau, 36 ${ }^{\circ} 54^{\prime} \mathrm{S} 71^{0} 31^{\prime}, 1270 \mathrm{~m}$, EI Schlinger, 28 January 1967 (1 male, 1 female) (S. Slope Bell Mtn., 3000', Ross and Michelbacher, 7 December 1950 (1 female); 17 December 1950 (2 males) EI Schlinger, 29 January 1967 (3 females); Araucania: Malleco: 18 Km Angol, Nahuelbuta Nac. Park, $37^{\circ} 48^{\prime} \mathrm{S} 72^{\circ}$ 43’, 620 m, EI Schlinger, 10 February 1967 (5 males, 1 female).

Notes. All geographic records are new.

\section{Apsil dilata Malloch, 1934}

(Figs. 9-12)

Diagnosis. Length $6.5 \mathrm{~mm}$. Gena very high, densely golden yellow dusted (Fig. 9); frons brown; antennae brown, apex of pedicel and base of flagellomere yellowish; palpus yellow, very dilated at apex, spoon like (Fig. 10); mesonotum with three brown vittae presuturally on acrostichal area, which are fused postsuturally; 2 lateral broader vittae reaching scutellum; scutellum with gray pollinosity, brown on lateral sides; legs brown with grayish pollinosity, apex of tarsi slightly yellowish brown; male: fore coxa with 4 strong setae on apical half of dorsal surface and with another parallel series of 4 less strong setae; hind coxa with 2 long and strong posterior spines (Fig. 11); hind femur and tibia not elongated; hind tibia not curved, with one anterodorsal supra median seta and 5 long and fine anteroventral on apical half, 3 posterodorsals on apical fourth; hind tarsus hardly more than half as long as hind tibia; abdomen brown with grayish pollinosity; with large subtriangular lateral brown marks on tergites $1+2-5$; male sternite 5 glossy brown and with short stiff black apical setae on the apex of the outstanding process (Fig. 12).

Notes. Malloch (1934) in the original description called attention to the color of the scutellum, entirely dark brown. The examined specimen has the scutellum gray pollinose and brown only lateral sides, but all other characters are coincident.

Material examined. CHILE: Nuble: Las Trancas: 2-7 Km Las Trancas, Malaise, EI Schlinger, 29 January 1967 (1 male).

Apsil maculiventris Malloch, 1934

(Figs. 13-19, 25)

Diagnosis. Length 6-7 mm. Gena very high, golden yellow dusted (Fig. 13); frons brown, with gray pollinosity; antennae yellow, some females with apex of flagellomere somewhat brown; palpus yellow, very dilated at apex (Fig. 14); dorsum of mesonotum as in Fig. 15; scutellum brown with grayish pollinosity, with sides brown; legs with coxae, femora and tarsi brown with grayish pollinosity; tibiae yellow to light brown, contrasting with femora color; fore femur with the row of posteroventral setae much stouter than the one on posterodorsal, especially on females (Fig. 16); males with about 4 series of thin setae on basal fifth of ventral surface. Male hind leg: hind coxa with a clump of short setae on posteroventral surface; hind femur and tibia elongated; hind femur with a complete row of anterodorsal and anteroventral setae; posteroventral surface with a clump of short sub-basal setae (Fig. 17); hind tibia slightly curved, long fine hairs on apical third of posterodorsal and dorsal surfaces (Fig. 18), one median anterodorsal, one median and one sub-median anteroventral; hind tarsi short about half of tibia length; abdomen brown with grayish pollinosity; with large subtriangular lateral brown marks on tergites $1+2-5$ in males and on tergites 1+2-4 in females; tergite 5 in females with 2 longitudinal brown vittae; male sternite 5 glossy and without outstanding process (Fig. 19).

Female. Length 6-7 mm

Similar to male, differing mainly in the bristling of hind leg: hind coxa without a clump of short setae on posteroventral surface; hind femur and tibia not so elongated as in male and tibia not curved; hind femur without a posteroventral clump of short sub-basal setae; hind tibia without fine hairs on apical third of posterodorsal and dorsal surfaces, but with about 6 setae, in two series on both surfaces; median anterodorsal and median and sub-median anteroventral as is male.

Ovipositor. Long, covered with microtrichia; all tergites and sternites straight, sternite 7 small (Figs 25 and 26).

Color variation. The color of the tibiae is less yellow in female, but at least the fore tibia contrasts with femur grey color.

Material examined. CHILE: Região Metropolitana: Santiago: Quebrada de la Plata Fundo, near Maipu, $33^{\circ} 30^{\prime} \mathrm{S} 70^{\circ} 55^{\prime} \mathrm{W}, 510 \mathrm{~m}$, ME Irwin, Malaise, 2 February 1966 (1 male, MNRJ); 9 February 1966 (1 female); 21 February 1966 (1 male); 9 March 1966 (1 female); 16 March 1966 (1 male); Maipu, Rinconada, 30 31' S 70 47' W, 20 February 1966 ( 1 female, MNRJ); 3 April 1966 ( 1 male); 33 $30^{\prime}$ S $70^{\circ}$ 55' WE Schlinger, 14 January 1966 (1 female); El Canelo: $33^{\circ} 35^{\prime}$ S $70^{\circ}$ 27' W, ME Irwin, 9 January 1966 (1 female); Nuble: Las Trancas: S. Slope Bell Mtn., 3000', Ross and Michelbacher, 17 December 1950 (1 male). Araucania: Malleco: $18 \mathrm{Km}$ Angol, Nahuelbuta Nac. Park, $37^{\circ}$ 48' S 720 43', 620 m, EI Schlinger, 10 February 1967 (1 male, 1 female).

Notes. A. maculiventris was known only from the male holotype and one paratype, both deposited at National Museum Natural History (Washington, USA), so the female is herein described and illustrated for the first time. All geographic records are new. The species was previously recorded only from Perales (Atacama).

Apsil mallochi, new species

(Figs. 20-22, 27-32)

Diagnosis. Length $5 \mathrm{~mm}$. Gena very high, golden yellow 

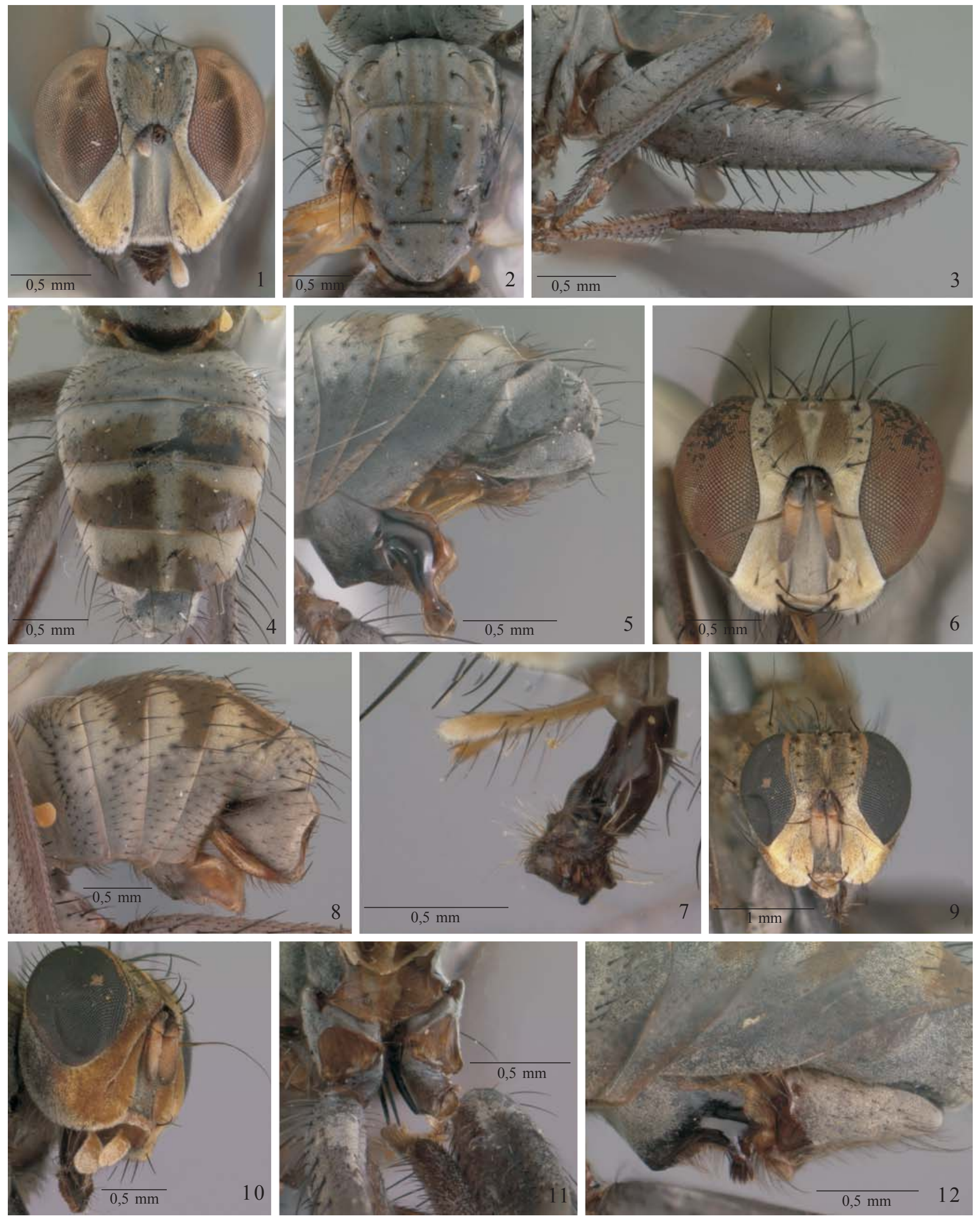

Figs. 1-12. 1-5, A. apicata Malloch, 1934. 1, Head of male, frontal view; 2, Mesonotum of male, dorsal view; 3, Hind femur and tibia of male; 4, Abdomen of male, dorsal view; 5, Abdomen of male, lateral view. 6-8, A. atripes Malloch, 1934. 6, Head of male, frontal view; 7, Palpus and proboscis of male, lateral view; 8, Abdomen of male, lateral view. 9-12, A. dilata Malloch, 1934. 9, Head of male, frontal view; 10, Palpus of male, lateral view; 11, Hind coxa of male, posterior view; 12, Abdomen of male, lateral view. 

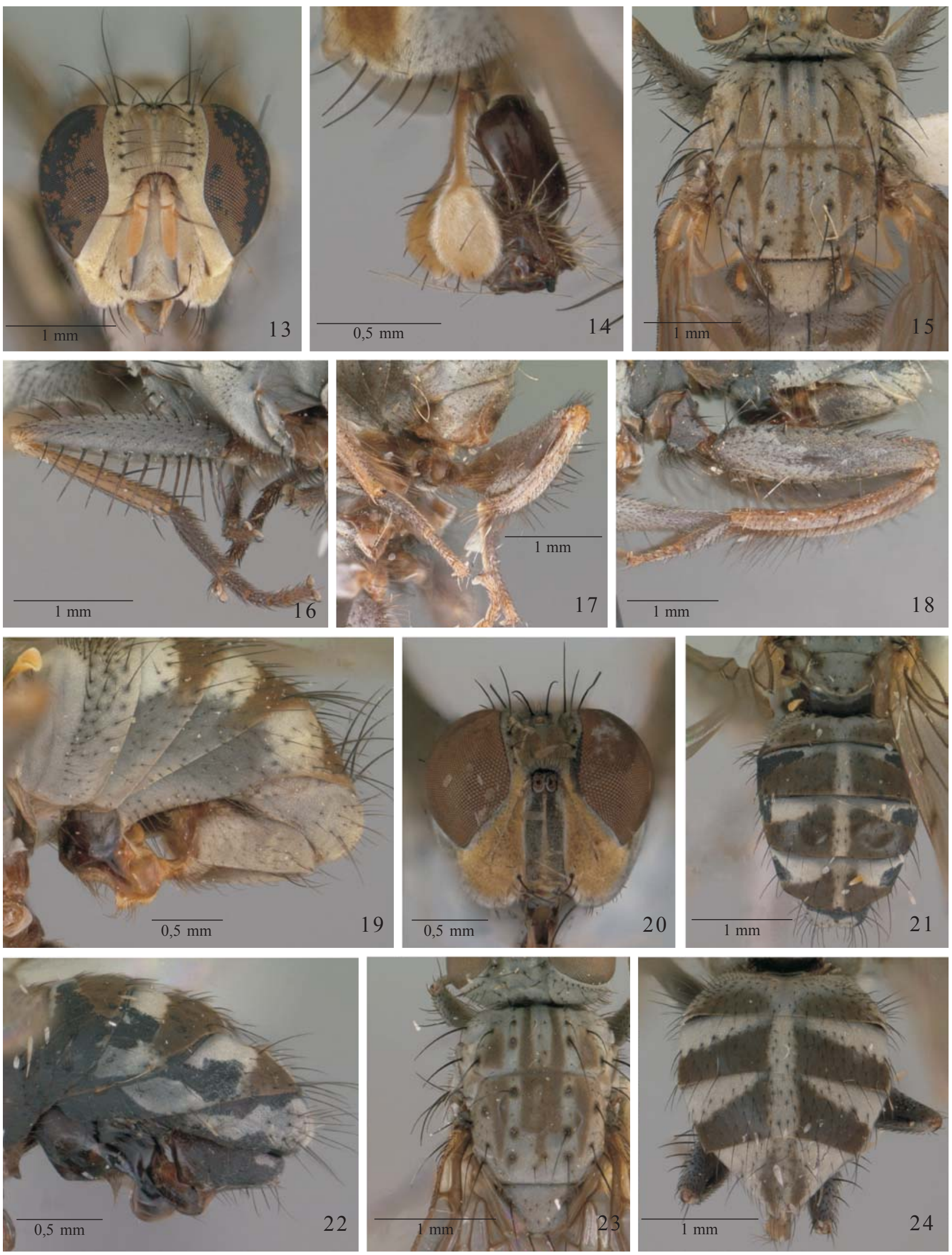

Figs. 13-24. 13-19, A. maculiventris Malloch, 1929. 13, Head of male, frontal view; 14, Palpus and proboscis of male, lateral view; 15, Mesonotum of male, dorsal view; 16, Fore femur and tibia of female; 17. Hind coxa and femur of male, posterior view; 18, Hind coxa and tibia of male, anterior view; 19, Abdomen of male, lateral view. 20-22, A mallochi Couri, sp. nov. 20, Head of male, frontal view; 21, Abdomen of male, dorsal view; 22, Abdomen of male, lateral view. 23-24, A. spatulata Malloch, 1934. 23, Mesonotum of female, dorsal view; 24, Abdomen of male, dorsal view. 


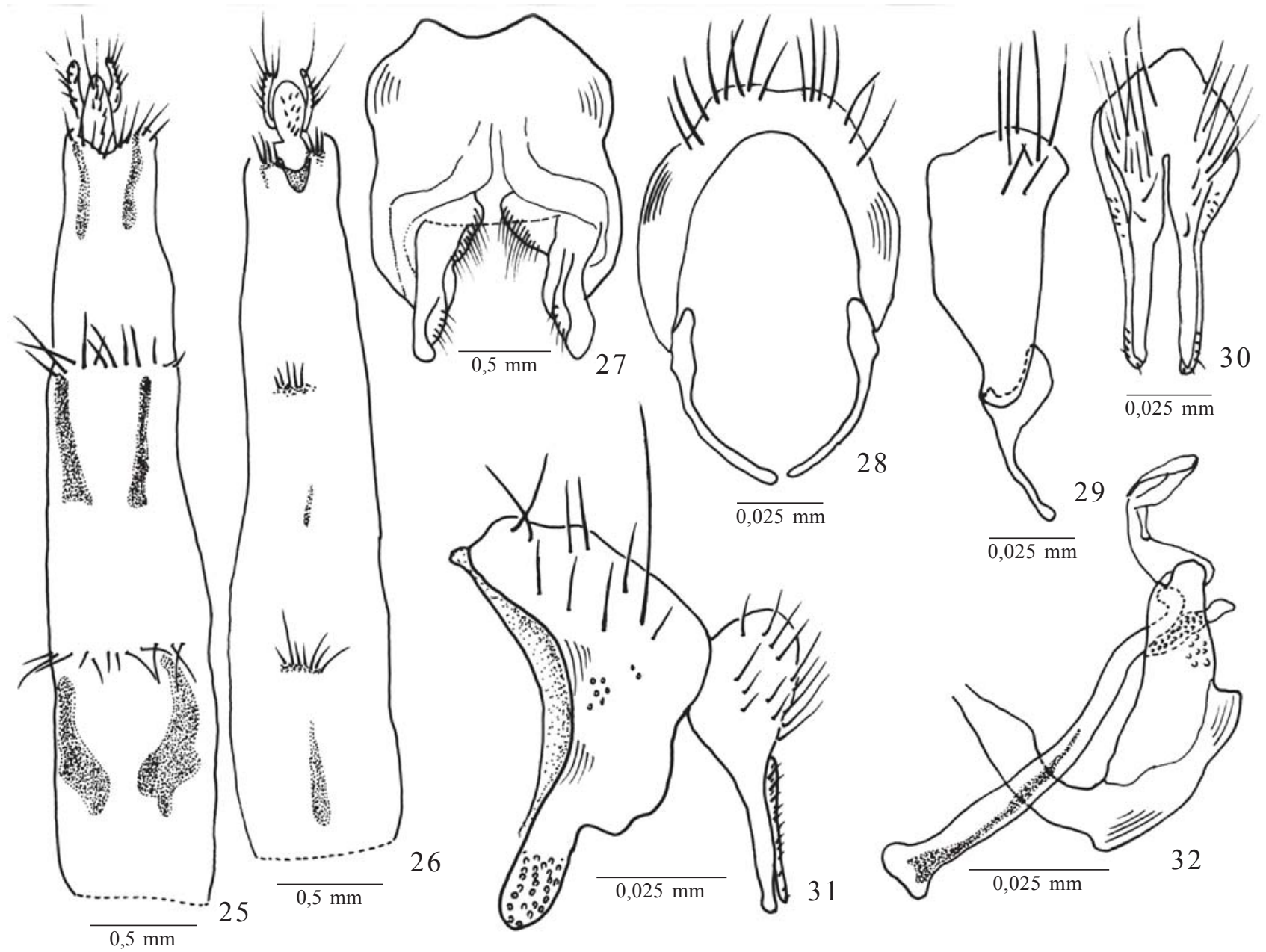

Figs. 25-32. 25-26, A. maculiventris Malloch, 1929. 25, Ovipositor, dorsal view; 26, Ovipositor, ventral view. 27-32, A. mallochi, sp. nov. 27, Sternite 5 of male, dorsal view; 28, Sternite 6 of male, dorsal view; 29, Sternite 6 of male, lateral view; 30, Cercal plate and surstyli of male, dorsal view; 31, Cercal plate and surstyli, lateral view; 32, Aedeagus, lateral view.

dusted (Fig. 20); frons brown, with gray pollinosity; antennae brown, apex of pedicel and base of flagellomere yellowish; palpus yellow, slightly dilated at apex; mesonotum with 4 brown vittae presuturally and 5 postsuturally, the ones in acrostichal area more or less fused; scutellum brown with grayish pollinosity, with sides brown; legs brown with grayish pollinosity; all tarsi yellow; fore femur with the row of posteroventral setae not stouter than the one on posterodorsal; males hind femur and tibia elongated; hind tibia curved, with a long and fine anterodorsal supramedian seta, 4 long and fine anteroventral on apical half, and a row of long and fine posterodorsal setae on apical two thirds; hind tarsus short about half of tibia length; abdomen brown with grayish pollinosity; with large sub-triangular lateral brown marks on tergites 1+2-5 (Fig. 21); male sternite 5 all glossy brown and with a big and round outstanding process (Fig. 22).

Male. Length. Body: $5 \mathrm{~mm}$, wing: 5.5

General coloration. Frons brown; fronto orbital plate brown, grey pollinose; gena golden yellow dusted; lateral and posterior portions of the head grey pollinose; palpus yellow. Antenna brown, grey pollinose and with with apex of pedicel and base of flagellomere yellow. Vittae on dorsum of mesonotum as in A. spatulata (Fig. 23); pleurae concolors with mesonotum. Calypters whitish and halter yellow. Wing hyaline, with brown marks on both cross veins. Legs brown with grayish pollinosity; all tarsi yellow. Abdomen brown with grayish pollinosity; with large sub-triangular lateral brown marks on tergites 1+2-5 (Fig. 21).

Head. Dichoptic, frons at vertex about one third of the head width; anterointernal facets developed. Frontal row with 4 pairs of setae. Vertical internal and external developed, as long as ocellar setae. Antenna short, inserted at medium level of eyes; flagellomere about 1.8 the pedicel length. Palpus slightly dilated at apex.

Thorax. Dorsocentrals 2:3; acrostichals very thin and short, 2 presutural pairs and 4 postsutural; 1 postpronotal; 1 presutural; 2 intralars; 1 supralar; 2 post-supralares. Notopleuron with two setae, the posterior one a little shorter than the anterior. Scutellum with one long basal and one long apical pair of setae, similar in size. Anepisternum with a series of 5 long and short setae. Katepisternals 1:1:1, forming an equilateral triangle. Inferior calypter about 1.8 the length of 
the superior. Wing veins bare. Fore femur with the row of posteroventral setae not stouter than the one on posterodorsal; fore tibia with one median posterior seta; mid femur with 4 long and fine posteroventral setae on basal half; 4 short anterodorsals on basal third; 2 posterodorsals and a much shorter one very close to base; mid tibia with one anterior and one posterior median setae; hind femur and tibia elongated; hind femur with a complete row of anterodorsal and anteroventral setae; hind tibia curved, with one long and fine anterodorsal supramedian seta, 4 long and fine anteroventral on apical half, and a row of long and fine posterodorsal setae on apical two thirds; hind tarsus short about half of tibia length.

Terminalia. - Sternite 5 glossy and with a big and round outstanding process (Figs 22 and 27). Sternite 6 with arms symmetric (Figs 28 and 29). Cercal plate and surstyli straight and long (Figs 30 and 31). Hypandrium and aedeagus as in Fig. 32.

Female - unknown

Type-material. Male holotype, deposited at CAS, labeled: "CHILE: Nuble: Las Trancas: 2-7 Km Las Trancas, Malaise, EI Schlinger, 29 January 1967 (1 male).

Notes. A. mallochi can be easily distinguished from its congeners by the quaetotaxy of hind tibia and the color of male sternite 5 and the large round shape of its process.

The name of this species is dedicated to John R. Malloch for his great contribution to the knowledge of Apsil genus.

\section{Apsil spatulata Malloch, 1934}

(Figs. 23-24)

Diagnosis. Length 5.5-7 mm. Gena high, yellow dusted; frons brown, with gray pollinosity; antennae brown, apex of pedicel and base of flagellomere yellowish; palpus yellow, dilated at apex; dorsum of mesonotum with four brown vittae presuturally, the median ones fused behind suture and continuing until close to scutellum as one median fine vitta (Fig. 23); scutellum brown with grayish pollinosity, with lateral sides brown; legs brown with grayish pollinosity; fore coxa with about 5 strong curved posterodorsal setae; fore femur with the row of posteroventral setae much stouter than the one on posterodorsal; hind femur and tibia not elongated; hind femur with a complete row of anterodorsal and anteroventral setae; hind tibia not curved in females, one supramedian anterodorsal seta; 3-4 thin anteroventrals on middle third; abdomen brown with grayish pollinosity; with large subtriangular lateral brown marks on tergites $1+2-4$; tergite 5 with 2 longitudinal brown vittae (Fig. 24); sternite 5 with an outstanding process bearing fulvous yellow hairs.

Material examined.- CHILE: Maule: Curico, Fundo la Montana, Estero la Palma at Rio Teno, $6 \mathrm{Km}$ E. los Quenes, $150 \mathrm{~m}$, ME Irwin, 4 January 1967 (1 female). Nuble: Las Trancas: 2-7 Km Las Trancas,
Malaise, EI Schlinger, 28 January 1967 (1 female); 29 January 1967 (1 female); 1320 m, ME Irwin and LA Stange, 15 January 1967 (1 female); Las Cabras, 1560 m, 16 February 1967 (1 female);

Notes. All geographic records are new. The species was previously known only from Peulla and Puntra in Los Lagos, Chile. The first three females listed on the examined material are much smaller than the fourth. Malloch (1934) also called attention to a possible variation in size in this species. No males among the examined series. Male characters in the above diagnosis were taken from Malloch (1934).

Acknowledgments. I gratefully acknowledge Norman Penny and all staff colleagues at the California Academy of Sciences, San Francisco, California for their support during this study, and also to Nick Olgeirson and April Anobile for the assistance with the automontage equipment; Darrel Ubick and Diana Silva D'Avila for the facilities in the "Wet Lab"; Larry Currie for the assistance in the library and Christine Arata for the every day help. I am also thankful to Coordenação de Aperfeiçoamento de Pessoal de Nível Superior (CAPES, process 3123-04-9), an agency of the Brazilian Government fostering scientific and technological development, for the postdoctoral grant.

\section{REFERENCES}

Carvalho, C. J. B. de \& M. S. Couri. 2002. Cladistic and biogeographic analyses of Apsil Malloch and Reynoldsia Malloch (Diptera: Muscidae) of southern South America. Proceedings of the Entomological Society of Washington 104: 309-317.

Carvalho, C. J. B. de; M. S. Couri; A. C. Pont; D. Pamplona \& S. M. Lopes. 2005. A Catalogue of the Muscidae (Diptera) of the Neotropical Region. Zootaxa 860: 1-282.

Couri, M. S. 2000. A revision of the genus Apsil Malloch (Diptera, Muscidae, Coenosiinae, Coenosiini). Studia dipterologica 7: 45-57.

Couri, M. S. 2002. A new species of Apsil Malloch from Chile (Diptera, Muscidae). Revista Brasileira de Zoologia 19: 105-108.

Couri, M. S. \& C. J. B. de Carvalho.2002. Part II. Apical groups, p. 133-287. In: C. J. B. de Carvalho (ed.). Muscidae (Diptera) of the Neotropical Region: taxonomy. Curitiba, Editora Universidade Federal do Paraná, 287 p.

Couri, M. S. \& A. C. Pont. 2000. Cladistic analysis of Coenosiini (Diptera: Muscidae: Coenosiinae). Systematic Entomology 25: 373-392

Malloch, J. R. 1929. Exotique Muscaridae (Diptera) - XXVI. Annals and Magazine of Natural History 4: 97-120.

Malloch, J. R. 1934. Muscidae. In: Diptera de Patagonia e South Chile. London, Part 7: 171346.

Morrone, J. J. 1993. Cladistic and biogeographic analyses of the weevil genus Listroderes Schoenber (Coleoptera, Curculionidae). Cladistics 9: 397-411

Morrone, J. J. 1994. Distributional patterns of the species of Rhytirrhinini (Coleoptera, Curculionidae) and the historical relationships of the Andean provinces. Global Ecology and Biogeography Letters 4: 188-194.

Morrone, J. J.; S. R. Junent \& J. V. Crisci. 1994. South American Beetles. National Geographical Research and Exploration 10: 104-115.

Morrone, J. J.; L. Katinas \& J. V. Crisci. 1997. A cladistic biogeographic analysis of Central Chile. Journal of Comparative Biology 2: $25-42$. 